\title{
Research on the Industrial Competition Capacity \& Economic Development of Huizhou City
}

\author{
Luo Zhi Quan ${ }^{1}$ Li Yanfei $^{2}$ Deng Jie ${ }^{3}$ Peng Wenli $^{1^{*}}$ \\ ${ }^{1}$ The First Affiliated Hospital, Jinan University, Guangzhou 510632 P.R.China; \\ ${ }^{2}$ Department of International Economics and Trade, Guangdong University of Foreign Studies \\ South China Business College, Guangzhou, 510545, P.R.China; \\ ${ }^{3}$ Jinan University, Guangzhou 510632 P.R.China; \\ *Corresponding author: Peng Wenli E-mail:kyk8034@126.com
}

Keywords: Huizhou City; Industrial Competition Capacity; Index System

Abstract. This paper first analyzes the economic development of Huizhou city including its GDP, general fiscal revenue, analysis of the structure of its three industries and so on. Based on that, the evaluation index system of Huizhou industrial competition capacity is put forward, together with related data collected and the calculation and analysis of solid evidence conducted. The results shows that its industrial competition capacity ranks relatively high among the cities in Guangdong province.

\section{Introduction}

In 2004, "people-oriented, independent innovation, key breakthrough, supporting and leading the economy and society to coordinated and sustainable development" was enacted as the future science \& technology development guidelines by the research group of state plans for medium and long-term development of science \& technology. " Science \& technology supporting and leading economic development" was proposed for the first time. Since then, government circles and academia begin to attach great importance to the study of it. As defined, the science and technology resource has become to be the first element for economic growth exceeding labor force and capital elements, which can meet the quality and quantity needs of economic growth also satisfy the wants of various industries'development and fulfill the great-leap-forward development demands of post-developing countries. Owing to the past limit of China science \& technology and economic development level, the study about the relations between economy and science \&technology led by Chinese scholars lag far behind than developed countries'. However, the related studies are increasing more year by year as China's strength growing in science \& technology and economy, in addition to the trend of focus on science\& technology competition in international competition in 1990s.

In recent years, Huizhou economy is increasing at a high speed. Besides, the outstanding characteristics of Huizhou city are as below: too high degree of foreign trade dependence, manufacturing vast majority of low-to-middle-end goods, relying on excellent ports to produce and export goods at a fast speed, competing by lower labor cost advantage, etcetera in international market. The paper discusses the input and output of science \& technology deeply from many aspects, and the coordination problems between science \& technology development. Meanwhile, the comprehensive evaluation index system is established. On this basis, conduct solid evidence analysis to broaden the research idea of " Science \& technology supporting and leading economic development”.

\section{A Comprehensive Analysis of Huizhou City's Economic Basis}

\subsection{The Development Status of Huizhou City's Gross Domestic Product (GDP).}

Table 1 shows the gross domestic product (GDP) development status of Huizhou city in recent years (2006 2011). It's knowable that the city's GDP presented an overall upward trend year after year from 92.89 billion yuan in 2006 to 209.73 billion yuan in 2011. The growth rate was fluctuated. 
Table 1: The development status of Huizhou city’s gross domestic product (GDP) in recent years (Huizhou statistical yearbook, 2012)

\begin{tabular}{lllllll}
\hline Year & 2006 & 2007 & 2008 & 2009 & 2010 & 2011 \\
\hline $\begin{array}{l}\text { GDP (100 million) } \\
\begin{array}{l}\text { Increase over the } \\
\text { previous year (\%) }\end{array}\end{array}$ & $\mathbf{1 6 . 8}$ & 1117.9 & 1304.0 & 1414.7 & 1730.0 & 2097.3 \\
\hline
\end{tabular}

\subsection{The Condition of Huizhou City's General Budgetary Revenue}

Table 2 shows the condition of Huizhou city's general budgetary revenue growth in recent years $(2006$ 2011). From table 2.2, it's known that its general budgetary revenue showed an overall upward trend year after year in recent years.

Table 2 The condition of Huizhou city's general budgetary revenue growth in recent years (Huizhou statistical yearbook 2012)

\begin{tabular}{lcccccc}
\hline Year & 2006 & 2007 & 2008 & 2009 & 2010 & 2011 \\
\hline $\begin{array}{l}\text { General budgetary } \\
\text { revenue }\end{array}$ & 44.4 & 62.0 & 78.0 & 101.5 & 131.2 & 162.8 \\
$\begin{array}{l}\text { (100 million) } \\
\begin{array}{l}\text { Increase over the } \\
\text { previous year (\%) }\end{array}\end{array}$ & 28.0 & 39.6 & 25.7 & 30.1 & 29.2 & 31.3 \\
\hline
\end{tabular}

\subsection{Analysis of Huizhou City's Three Industrial Structure}

Table 3 shows the three industrial structure changes of Huizhou city form 2006 to 2011. Table 2.3 indicates a gradual decline trend of its first industry proportion fallen from $8.5 \%$ in 2006 down to $5.6 \%$ in 2011. However, the second industry ratio had maintained a high level all the time at about $60 \%$. while the tertiary industry one fluctuated around 35\%. According to statistics, the three industrial structure respective ratios of Guangdong province were: 5.0:49.7:45.3 in 2011. So it could judge that the second industry proportion of Huizhou city is relatively high, while its tertiary industry one is low among the city's three industrial structure. Therefore, it has become to be one of the most urgent tasks faced by Huizhou city to accelerate the rapid development of its tertiary industry.

Table 3: The condition of Huizhou city's three industrial structure (Huizhou statistical yearbook from 2006 to 2012 )

\begin{tabular}{lllllll}
\hline Year & 2006 & 2007 & 2008 & 2009 & 2010 & 2011 \\
\hline $\begin{array}{l}\text { Primary } \\
\text { industry }\end{array}$ & $8.5 \%$ & $7.1 \%$ & $6.9 \%$ & $6.4 \%$ & $5.9 \%$ & $5.6 \%$ \\
$\begin{array}{l}\text { Second } \\
\text { industry }\end{array}$ & $58.5 \%$ & $58.9 \%$ & $56.8 \%$ & $55.8 \%$ & $59.0 \%$ & $59.4 \%$ \\
$\begin{array}{l}\text { Third } \\
\text { industry }\end{array}$ & $33.0 \%$ & $34.0 \%$ & $36.3 \%$ & $37.8 \%$ & $35.1 \%$ & $35.0 \%$ \\
Total & 100 & 100 & 100 & 100 & 100 & 100 \\
\hline
\end{tabular}

\subsection{The Situation of Huizhou City's Foreign Trade and Foreign Trade Dependence Degree}

Table 4 reveals the foreign trade and foreign trade dependence degree alteration of Huizhou city from 2006 to 2011. From table 4, it is known that there was a upturn trend for the total volume of foreign exports and imports of Huizhou city. 
Table 4: The situation of Huizhou city's foreign trade and foreign trade dependence in recent years (unit: 100 million dollars, Huizhou statistical yearbook from 2006 to 2012 )

\begin{tabular}{lllllll}
\hline Year & 2006 & 2007 & 2008 & 2009 & 2010 & 2011 \\
\hline $\begin{array}{l}\text { Total imports \& exports of } \\
\text { foreign trade }\end{array}$ & 212.3 & 241.1 & 297.4 & 292.4 & 342.3 & 388.1 \\
$\begin{array}{l}\text { Total exports of foreign } \\
\text { trade }\end{array}$ & 122.8 & 146.1 & 179.9 & 171.5 & 202.3 & 231.2 \\
$\begin{array}{l}\text { Total imports of foreign } \\
\text { trade }\end{array}$ & 89.5 & 95.0 & 117.5 & 120.9 & 140.0 & 156.9 \\
$\begin{array}{l}\text { Thedegree of dependence on } \\
\text { foreign trade }\end{array}$ & $182.2 \%$ & $164.0 \%$ & $158.4 \%$ & $141.2 \%$ & $134.0 \%$ & $119.8 \%$ \\
\hline
\end{tabular}

There was a declining trend of its dependence degree on foreign trade from 2006 to 2011 . However, this index value is still relatively much higher. One of the major reasons for causing this phenomenon is that the second industry holds dominant position, while the tertiary industry development relatively lags behind in Huizhou city's GDP

\section{Analysis of Huizhou City's Industrial Competition Capacity}

\subsection{The Evaluation Index System Construction}

In the evaluation of industrial competition capacity, mainly consider input and output of industrial scale, production efficiency, growth, market influence and innovation ability of science \& technology as subsystem levels.There are14 evaluation index items established as shown in table 5. Table 5: The system of industrial competition capacity evaluation index

\begin{tabular}{|c|c|c|c|}
\hline Target layer & The subsystem layer & The index layer & Variable settings \\
\hline \multirow{14}{*}{$\begin{array}{l}\text { Industrial } \\
\text { competitiveness }\end{array}$} & \multirow{4}{*}{$\begin{array}{l}\text { Input } \\
\text { of scale }\end{array}$} & $\begin{array}{l}\text { Numbers of industrial enterprises above } \\
\text { designated Size (a) }\end{array}$ & $\mathrm{X} 1$ \\
\hline & & Total assets (100 million yuan) & $\mathrm{x} 2$ \\
\hline & & $\begin{array}{l}\text { The average number of employees (ten } \\
\text { thousand yuan) }\end{array}$ & X3 \\
\hline & & $\begin{array}{l}\text { Total industrial output value (100 million } \\
\text { yuan) }\end{array}$ & X4 \\
\hline & \multirow{3}{*}{$\begin{array}{l}\text { Output } \\
\text { of scale }\end{array}$} & Main business revenue (100 million yuan) & X5 \\
\hline & & Total profit (100 million yuan) & X6 \\
\hline & & The contribution rate of total assets (\%) & X7 \\
\hline & \multirow{2}{*}{$\begin{array}{l}\text { Production } \\
\text { performance }\end{array}$} & The cost profit margins (\%) & $\mathrm{X} 8$ \\
\hline & & All personnel labor productivity (\%) & X9 \\
\hline & \multirow{2}{*}{ Growth } & $\begin{array}{l}\text { Value added of industry (100 million } \\
\text { yuan) }\end{array}$ & $\mathrm{X} 10$ \\
\hline & & Industrial added value rate (\%) & X11 \\
\hline & Market influence & Product sales rate (\%) & X12 \\
\hline & \multirow{2}{*}{$\begin{array}{l}\text { Innovation ability of } \\
\text { science\& technology }\end{array}$} & $\begin{array}{l}\text { R\&D internal expenditure(ten thousand } \\
\text { yuan) }\end{array}$ & $\mathrm{X} 13$ \\
\hline & & $\begin{array}{l}\text { The ratio of R\&D internal expenditure } \\
\text { and GDP (\%) }\end{array}$ & X14 \\
\hline
\end{tabular}

\subsection{The Index Data Selection}

Table 6 shows the index data value of each city's industrial competition capacity in Guangdong province in 2011. From this table, it's clear to know that Shenzhen city, Guangzhou city and Foshan city data value ranked relatively higher, and Yunfu City, Shanwei city and Heyuan city data values were relatively lower for these evaluation indexes. 
Table 6: The each city's industrial and agricultural competition capacity index data value in Guangdong province in 2011(Guangdong statistical yearbook 2012)

\begin{tabular}{|c|c|c|c|c|c|c|c|c|c|c|c|c|c|c|}
\hline cities & $\mathrm{X} 1$ & $\mathrm{X} 2$ & $\mathrm{X} 3$ & $\mathrm{X} 4$ & X5 & $\mathrm{X} 6$ & $X 7$ & $\mathrm{X} 8$ & X9 & $\mathrm{X} 10$ & $\mathrm{X} 11$ & $\mathrm{X} 12$ & $\mathrm{X} 13$ & X14 \\
\hline Guangzhou & 4438 & 11831 & 154.7 & 15713 & 15270 & 958.5 & 15.5 & 6.61 & 259092 & 4008 & 25.51 & 97.56 & 1406661 & 1.13 \\
\hline Shenzhen & 5692 & 17396 & 341.1 & 20432 & 20557 & 1318 & 13. 46 & 6.74 & 139818 & 4769 & 23.34 & 98.06 & 3888917 & 3.38 \\
\hline Zhuhai & 893 & 3221 & 46. 39 & 3377 & 3464 & 165.6 & 8.28 & 4.89 & 145624 & 675.5 & 20.00 & 93.59 & 275089 & 1.96 \\
\hline Shantou & 1877 & 1392 & 34.95 & 1892 & 1820 & 139.9 & 14.96 & 8.32 & 119266 & 416.9 & 22.03 & 96.94 & 85658.6 & 0.67 \\
\hline Foshan & 6318 & 8843 & 171.5 & 14425 & 13958 & 1007 & 16. 14 & 7.59 & 174468 & 2991 & 20.74 & 97.63 & 1163528 & 1.87 \\
\hline Shaoguan & 408 & 939.5 & 15. 11 & 917.9 & 888.6 & 35.71 & 12.11 & 4. 02 & 160044 & 241.9 & 26.35 & 99.55 & 120865 & 1. 48 \\
\hline Heyuan & 361 & 567.8 & 13.8 & 1041 & 978.6 & 118.9 & 27.73 & 14. 09 & 192304 & 265.4 & 25.49 & 95.18 & 8088.5 & 0.14 \\
\hline Meizhou & 340 & 515.1 & 10.95 & 546.8 & 508.1 & 34.89 & 18.96 & 6.84 & 147695 & 161.7 & 29.57 & 99.18 & 28522 & 0.40 \\
\hline Huizhou & 1428 & 3262 & 64.39 & 4765 & 4709 & 220.2 & 15.87 & 4.84 & 157402 & 1014 & 21.27 & 98.76 & 314606 & 1.50 \\
\hline Shanwei & 243 & 359.4 & 17.96 & 579.4 & 557 & 13.98 & 8.94 & 2.58 & 101951 & 183.1 & 31.60 & 97.33 & 23805.2 & 0.43 \\
\hline Dongguan & 4243 & 6613 & 252.4 & 8470 & 8455 & 316.5 & 7. 72 & 3.72 & 65087 & 1642 & 19. 39 & 99.6 & 612516 & 1.29 \\
\hline Zhongshan & 3170 & 3013 & 115.6 & 5747 & 5380 & 331.5 & 17. 44 & 6.48 & 106820 & 1235 & 21.49 & 96.23 & 460413 & 2.10 \\
\hline Jiangmen & 2766 & 2519 & 65.53 & 4671 & 4442 & 311.2 & 19. 46 & 7.52 & 163263 & 1070 & 22.90 & 95.49 & 225697 & 1.23 \\
\hline Yangjiang & 521 & 535.4 & 13. 18 & 964.5 & 940.5 & 98.61 & 26.37 & 12. 16 & 170654 & 224.9 & 23.31 & 97.01 & 31574.5 & 0.41 \\
\hline Zhanjiang & 651 & 1319 & 13. 05 & 1753 & 1661 & 114.4 & 18. 76 & 7.63 & 396669 & 517.5 & 29.53 & 95.8 & 29301.8 & 0.17 \\
\hline Maoming & 628 & 556.7 & 10.7 & 1704 & 1711 & 80.18 & 45.51 & 5.24 & 398248 & 426.2 & 25.01 & 98.01 & 51803.9 & 0.30 \\
\hline Zhaoqing & 1054 & 1413 & 31.87 & 2469 & 2367 & 168.2 & 19. 23 & 7. 61 & 179151 & 571 & 23.13 & 97.98 & 99961.6 & 0.75 \\
\hline Qingyuan & 635 & 1129 & 27.47 & 1752 & 1722 & 145.1 & 18. 22 & 9.26 & 132128 & 363 & 20.72 & 98.24 & 46095.8 & 0.46 \\
\hline Chaozhou & 726 & 509.1 & 19. 71 & 840.2 & 833.2 & 75.21 & 23.56 & 9.88 & 109502 & 215.8 & 25.68 & 99.51 & 44617.4 & 0.69 \\
\hline Jieyang & 1511 & 1032 & 33.05 & 2299 & 2287 & 185 & 26.69 & 8.92 & 165534 & 547 & 23.80 & 99.19 & 57138 & 0.47 \\
\hline Yunfu & 401 & 431.6 & 10.54 & 512.6 & 488. 1 & 35.67 & 14. 06 & 7.83 & 117443 & 123.8 & 24.14 & 96.71 & 19553 & 0.41 \\
\hline
\end{tabular}

\subsection{The Evaluation Methods}

The factor analysis method is mainly used to evaluate the industrial competition capacity. The 14 factors calculated from SPSS20.0 explain the total variance of the original variables as shown in table 7. The first factor's characteristic value is 8.454 which can explains $60.388 \%$ of the total 14 original variables' variance. Getting the cumulative variance contribution rate is $60.388 \%$. The second factor's characteristic value is 1.837 which can explain $13.123 \%$ of the total 14 original variables' variance. So the cumulative variance contribution rate is $73.511 \%$. The third factor's characteristic value is 1.279 which can explain $9.133 \%$ of the total variance of the total 14 original variables' variance. Obtaining the cumulative variance contribution rate is $82.643 \%$.The fourth factor's characteristic value is 1.01, which can explain $7.214 \%$ of the total variance of the total 14 original variables' variance. And the cumulative variance contribution rate is $89.857 \%$. Due to the fifth and subsequent factors' characteristic value is small, its contribution is also very small on the interpretation of the original variables. So 4 eigenvalues or eigenvectors can be extracted. It means that the most information of original variables can be obtained through the analysis of the 4 factors. 
Table7 : The total original variables' variance explained by the industrial competition capacity factors

\begin{tabular}{lllllll}
\hline \multirow{2}{*}{ Elements } & \multicolumn{2}{l}{ Initial eigenvalue } & \multicolumn{3}{l}{ Extraction of square and load } \\
\cline { 2 - 6 } & Total & $\begin{array}{l}\text { The percent } \\
\text { of variance }\end{array}$ & $\begin{array}{l}\text { Cumulative } \\
\text { percent }\end{array}$ & Total & $\begin{array}{l}\text { The percent } \\
\text { of variance }\end{array}$ & $\begin{array}{l}\text { Cumulative } \\
\text { percent }\end{array}$ \\
\hline 1 & 8.454 & 60.388 & 60.388 & 8.454 & 60.388 & 60.388 \\
2 & 1.837 & 13.123 & 73.511 & 1.837 & 13.123 & 73.511 \\
3 & 1.279 & 9.133 & 82.643 & 1.279 & 9.133 & 82.643 \\
4 & 1.010 & 7.214 & 89.857 & 1.010 & 7.214 & 89.857 \\
5 & .693 & 4.950 & 94.807 & & & \\
6 & .335 & 2.389 & 97.197 & & & \\
7 & .160 & 1.144 & 98.341 & & & \\
8 & .124 & .887 & 99.228 & & & \\
9 & .081 & .576 & 99.804 & & & \\
10 & .021 & .152 & 99.956 & & & \\
11 & .004 & .028 & 99.984 & & & \\
12 & .002 & .014 & 99.998 & & & \\
13 & .000 & .002 & 100.000 & & & \\
14 & $1.789 \mathrm{E}-5$ & .000 & 100.000 & & & \\
\hline
\end{tabular}

Each factor scores, total scores and ranking situations calculated by the SPSS software are shown in table 8.

Table 8: The scores and ranking of industrial competition capacity factors for Huizhou city and the other cities in Guangdong province.

$\begin{array}{llll}\text { The first principal } & \begin{array}{l}\text { The second } \\ \text { cities }\end{array} & \text { The third } & \text { The fourth } \\ \text { component } & \begin{array}{l}\text { principal } \\ \text { component }\end{array} & \begin{array}{l}\text { principal } \\ \text { component }\end{array} & \text { principal } \\ & \text { component }\end{array}$ total score ranking

\begin{tabular}{|c|c|c|c|c|c|c|}
\hline Huizhou & 0.09438 & -0.7401 & 0.3085 & 0.38833 & 0.02 & 6 \\
\hline Shenzhen & 3. 03246 & 0.50337 & 0.35537 & 0.0496 & 2.15 & 1 \\
\hline Guangzhou & 1. 54212 & 1. 24844 & 0.78588 & -0.51151 & 1.26 & 2 \\
\hline Foshan & 1.5961 & 0.41046 & -0.55245 & 0.34088 & 1.1 & 3 \\
\hline Dongguan & 0.93861 & -1.64933 & 0.33082 & 1. 11995 & 0.51 & 4 \\
\hline Zhongshan & 0.40162 & -0.67024 & -0.88404 & -0.40202 & 0.05 & 5 \\
\hline Maoming & -0.7546 & 2. 26944 & 1. 02828 & 0.3029 & -0.05 & 7 \\
\hline Jiangmen & 0.04823 & 0.03741 & -0.89395 & -0.78265 & -0.12 & 8 \\
\hline Jieyang & -0.44159 & 0.35426 & 0.05166 & 1. 42969 & -0.12 & 9 \\
\hline Zhaoqing & -0.36689 & -0.0825 & -0.08014 & 0.33393 & -0.24 & 10 \\
\hline Shaoguan & -0.43772 & -1.0548 & 1. 47615 & 0.06495 & -0.29 & 11 \\
\hline Chaozhou & -0.62341 & -0.09276 & 0.14783 & 1.53208 & -0.29 & 12 \\
\hline Zhanjiang & -0.68954 & 1.52356 & 0.86867 & -1.89492 & -0.3 & 13 \\
\hline Meizhou & -0.73214 & -0.1812 & 1. 38076 & 0.4391 & -0.34 & 14 \\
\hline Qingyuan & -0.4679 & -0.35406 & -0.77154 & 0.97591 & -0.37 & 15 \\
\hline Shantou & -0.33659 & -0.56373 & -0.81863 & 0.08039 & -0.39 & 16 \\
\hline Yangjiang & -0.69837 & 0.66865 & -1.20397 & 0.70012 & -0.44 & 17 \\
\hline Zhuhai & 0.01696 & -1.13524 & -1.38553 & -2.38459 & -0.49 & 18 \\
\hline Shanwei & -0.66629 & -1.15148 & 1.92213 & -1.34419 & -0.53 & 19 \\
\hline Heyuan & -0.80146 & 1. 28395 & -1.65506 & -0.11873 & -0.53 & 20 \\
\hline Yunfu & -0.65401 & -0.6241 & -0.41076 & -0.31924 & -0.6 & 21 \\
\hline
\end{tabular}

It can be seen from table 8 that Huizhou city's total score is 0.02 points ranking No. 6 . Thus can judge that Huizhou city's industrial competition capacity was in the front row among the 21 cities in 
Guangdong province in 2011. The data suggests that Huizhou city owns a very strong competitive strength among the cities in Guangdong province.

\section{Conclusion}

Science and technology supporting economic development is not only one of the most prominent issues for Huizhou city current and future economic society's development, but also is the popular concerned issue by the government and people. Combined with the actual situation of Huizhou city, this paper studies its economic strength and industrial competitiveness. Research results will be provided to Huizhou local science \& technology management department and experts for their decision-making counseling, which also have significant reference to formulating and implementing scientific development plan of science \& technology and economy.

\section{References}

[1]Huizhou Municipal Science and Technology Bureau.In 2011, the authorization of Guangdong province patent application [J]. Huizhou Science and Technology, 2011 (6).

[2]Huizhou Municipal Science and Technology Bureau.Independent innovation to let Huizhou go farther, cultivating a number of high-tech enterprise [EB/OL]. Guangdong Provincial Department of Science and Technology Network, [2012-12-28].

[3]Minyi Liu. Research on the cooperation escort innovation of production in Huizhou of Guangdong [EB/OL]. Chinese Innovation Network, [2012-12-28].

[4]Haitao Zhang. The main measures to encourage technological innovation of American [J]. Policy, 2008 (2).

[5]Hongyu Chen. The experience and enlightenment of science and technology achievement in developed countries[J]. Achievements of Science and Technology, 2009 (5).

[6]Xiong Ying.Some enlightenment of Japanese government support for the innovation of science and technology[J]. Zhejiang Economy, 2008 (22).

[7] Dongxue Hu. Policy is the main means of the government to guide scientific and technological innovation [J]. East China Science and Technology, 2012 (10).

[8] Kai Hu. Research on the government procurement policy of supporting to enterprise innovation activities [J]. Science \& Technology Progress and Policy, 2008 (8).

[9] Guojin Chen. The effective mechanism of financial support for science and technology progress [J]. Fujian Journal of Jiangxia University, 2012 (1).

[10] Yueqiu Cheng. Quantitative analysis of technology progress to promote the economic development of Zhejiang[J]. Zhejiang Statistics, 2005 (5). 